\title{
KESADARAN PERSEPSI TENTANG \\ KEADILAN DAN KUALITAS PELAYANAN PAJAK TERHADAP KEPATUHAN WAJIB PAJAK RESTORAN DI KOTA PALU
}

\author{
Ni Nyoman Kristian Mediawati \\ Sekolah Pascasarjana Fakultas Ekonomi dan Bisnis Universitas Airlangga \\ nyomanmediawati@protonmail.com
}

ARTICLE HISTORY

Received:

1 June 2018

Revised

6 July 2018

Accepted:

22 August 2018

Online available:

10 November 2018

Keywords :

The taxpayer

awareness,

Fairness Perceptions,

\begin{abstract}
Tax Compliance issue is a constraint in optimizing tax revenue. Tax compliance is the main thing that supports the course of the selfassessment system which in this system obligatory role of the taxpayer is required to realize the achievement of tax revenue. Through optimal effort, DPPKAD always trying to explore the potential tax revenue by raising awareness, public facilities and the quality of their fulfillment of tax services.

This study focuses on the awareness of the taxpayer based on the research Suryadi (2008). Perceptions of fairness based on the research that has been conducted by Saad (2009). Tax and service quality based on the research that has been done by Umaimah (2011).

This study uses multiple linear regression with taxpayer data obtained from the Office of Financial Management Services Regional Asset registered until 2013. This study proves that the awareness, perceptions of fairness and quality of service significant and positive impact on tax compliance restaurants in the city of Palu
\end{abstract}




\section{LATAR BELAKANG}

Pajak mempunyai peranan yang sangat penting dalam kehidupan bernegara, khususnya di dalam melanjutkan pembangunan karena merupakan sumber biaya untuk membiayai pengeluaran negara. Volume penerimaan dalam negeri terutama dari pajak senantiasa diupayakan untuk terus meningkat, karena erat kaitannya dengan upaya peningkatan kepatuhan wajib pajak dalam melaksanakan hak dan kewajibannya di bidang perpajakan sesuai dengan ketentuan peraturan perundang-undangan perpajakan yang berlaku.

Salah satu tujuan pelaksanaan otonomi daerah dan disentralisasi fiskal adalah untuk meningkatkan kemandirian daerah dan mengurangi ketergantungan fiskal terhadap pemerintah pusat. Peningkatan kemandirian daerah sangat erat kaitannya dengan kemampuan daerah dalam menge-lola Pendapatan Asli Daerah (PAD).

Pajak restoran merupakan salah satu sumber Penerimaan Asli Daerah (PAD) yang memiliki peran untuk membiayai pe-nyelenggaran pemerintah dan pembangunan daerah. Berdasarkan Pasal 2 ayat 2 Undang-undang No. 28 tahun 2009, pajak restoran merupakan jenis pajak kabupaten/kota. Sebagai salah satu unsur dari PAD, maka pajak restoran memiliki peran untuk membiayai pengeluaran-pengeluaran pemerintah daerah yang akhirnya kembali lagi dipergunakan untuk kepentingan masyarakat.

Kota Palu selain merupakan ibu kota provinsi Sulawesi Tengah jika dibandingkan dengan provinsi lain di Sulawesi, kota Palu saat ini memiliki tingkat pertumbuhan ekonomi yang tinggi dan sedang dalam ting-kat pengembangan daerah. Secara umum perekonomian di Kota Palu mengalami peningkatan pada tahun 2013 yaitu sebesar 10,96\%. Pendapatan Domestik Regional Bruto (PDRB) kota Palu tahun 2013 adalah sebesar Rp 3.624.204,00 sedangkan tahun 2012 hanya Rp 3.305.958,00.

Dalam harian ANTARSULTENG (www.antarasulteng.com) disebutkan bahwa peningkatan ekonomi tersebut terjadi pada semua sektor. Sektor restoran dan hotel memberikan kontribusi terbesar kedua setelah perdagangan Rp 490.51.

Fenomena yang terjadi adalah target dan realisasi dari pajak hotel dan restoran selama 5 tahun terakhir. Pajak restoran realisasi penerimaannya tergolong rendah bahkan pada tahun 2009 dan 2010 terjadi target yang tidak tercapai, sedangkan pada pajak hotel dari tahun 2009 sampai pada tahun 2013 target penerimaan pajak selalu terealisasi. Hal ini perlu mendapatkan perhatian khusus.

Menurut Devas (1989:5) masalah yang dihadapi dalam menentukan potensi pajak dapat teridentifikasi dengan baik dan tidak semua wajib pajak dapat dinilai secara benar. Dari hasil pengamatan di DPPKAD kota Palu, pajak restoran merupakan wajib pajak yang tingkat kepatuhannya rendah yaitu dari 351 wajib pajak yang terdaftar hanya 131 wajib pajak yang melaporkan pajak terutangnya. 
Berdasarkan pasal 3 Peraturan Peme-rintah Nomor 91 tahun 2010 sebagai peraturan pelaksana dari UU Nomor 28 Tahun 2009, pajak restoran merupakan jenis pajak yang dipungut berdasarkan penetapan (self assessment). Sistem self assessment merupakan sistem yang diterapkan untuk mem-beri tanggung jawab penuh kepada wajib pajak yang mana wajib pajak berkewajiban menghitung, memperhitungkan dan melaporkan pajak terutangnya.

Agar self assessment sytem dapat berjalan dengan baik, pemerintah dalam hal ini Direktorat Jendral Pajak seharusnya menjalankan ke 3 (tiga) fungsinya yaitu pelayanan (tax service), penyuluhan (dissemination), dan penegakan hukum (law enforment) secara optimal. Self assessment system mengandung hal penting yang diharapkan ada dalam diri wajib pajak yaitu kesadaran wajib pajak, kejujuran wajib pajak, kedisiplinan wajib pajak dan hasrat untuk membayar pajak Soemitro (1991:5).

Berdasarkan fenomena yang terjadi saat ini maka topik penelitian ini adalah "Pengaruh Kesadaran, Persepsi tentang Keadilan dan Kualitas Pelayanan terhadap Kepatuhan Wajib Pajak Restoran di Kota Palu".

\section{TINJAUAN PUSTAKA}

\section{Kesadaran}

Menurut Musyarofah dan Purnomo (2008) kesadaran wajib pajak adalah “sikap mengerti wajib pajak badan atau perorangan untuk memahami arti, fungsi dan tujuan membayar pajak". Oleh karena itu kesadaran merupakan faktor terpenting dalam sistem perpajakan modern. Musyarofah dan Purnomo (2008) mengatakan bahwa diperlukan kesadaran wajib pajak dalam membayar pajak kepada negara guna mem-biayai pembangunan negara demi kepentingan dan kesejahteraan umum.

Kesadaran wajib pajak dibentuk oleh 3 (tiga) dimensi persepsi wajib pajak, pengetahuan wajib pajak, karakteristik wajib pajak dan penyuluhan perpajakan. Kesadaran wajib pajak akan meningkat bila-mana dalam masyarakat muncul persepsi positif terhadap pajak (Suryadi, 2006).

\section{Persepsi tentang Keadilan}

Saad (2009) mengatakan bahwa ke-adilan adalah hubungan timbal balik antara kontribusi yang dibayar oleh wajib pajak dengan manfaat yang dirasakan. Wajib pajak akan memiliki persepsi yang adil dari sistem perpajakan jika manfaat yang diteri-ma sebanding dengan kontribusi yang di-berikan.

Menurut Azmi dan Perumal (2008), persepsi tentang keadilan sulit didefinisi-kan karena 4 (empat) masalah utama:

1. merupakan masalah dimensional

2. dapat didefinisikan pada tingkat in-dividu maupun pada masyarakat luas

3. Keadilan terkait dengan komplek-sitas. 
4. Kurangnya keadilan dapat menjadi-kan pertimbangan atau menyebaban ketidakpatuhan.

\section{Kualitas Pelayanan}

Kualitas pelayanan (service quality) merupakan kunci utama dari pelayanan publik yang diberikan kepada masyarakat. Kualitas pelayanan merupakan tingkat keunggulan yang diharapkan dan pengendali-an atas tingkat keunggulan tersebut untuk memenuhi keinginan pelanggan. Dengan adanya service quality yang baik dan prima maka akan tercipta suatu persepsi yang baik dari masyarakat terhadap pelayanan yang diberikan. Persepsi yang baik akan timbul, dan kemudian akan menjadi perasaan puas dari masyarakat karena telah memenuhi harapan yang diinginkan oleh masyarakat tersebut (Prianggono dan Manupputy, 2011). Menurut Oentari dan Mangoting (2013), pelayanan di sektor perpajakan dapat diartikan sebagai berikut:

"Pelayanan yang diberikan kepada Wajib Pajak oleh Direktorat Jen-dral Pajak untuk membantu Wajib Pajak memenuhi kewajiban per-pajakannya. Pelayanan pajak ter-masuk dalam pelayanan publik karena dijalankan oleh instansi pe-merintah, bertujuan untuk meme-nuhi kebutuhan masyarakat mau-pun dalam rangka pelaksanaan un-dang-undang dan tidak berorientasi pada profit atau laba".

\section{Kepatuhan Wajib Pajak}

Albari (2008) mendifiniskan kepatuh-an sebagai "sikap yang rela untuk melakukan segala sesuatu yang di dalamnya di-dasari kesadaran maupun adanya paksaan yang membuat perilaku seseorang dapat sesuai dengan yang diharapkan". Berkaitan dengan kewajiban pembayaran pajak maka kepatuhan dalam membayar pajak juga merupakan sikap prioritas warga Negara. Pada prinsipnya orang yang patuh itu ialah orang yang memiliki keputusan untuk memilih taat membayar pajak dan taat terhadap hukum.

Nurmantu (2003:148) mendifinisikan "kepatuhan perpajakan dapat didefinisikan sebagai suatu keadaan di mana Wajib Pajak memenuhi semua kewajiban perpajakan dan melaksanakan hak perpajakannya".

\section{Pajak Daerah}

Menurut Siahaan (2010:7) pajak daerah adalah "iuran wajib yang dilakukan oleh daerah kepada orang pribadi atau badan tanpa imbalan langsung yang seimbang, yang dapat dipaksakan berdasarkan peraturan perundang-undangan yang berlaku, yang digunakan untuk membiayai penyelenggaraan pemerintah daerah dan pembangunan daerah".

\section{Pajak Restoran}

Sesuai dengan Undang-undang nomor 28 tahun 2009 Pasal 1 angka 22 dan 23, pajak restoran adalah "pajak atas pelayanan yang disediakan oleh restoran. Restoran adalah fasilitas penyedia makanan dan atau minuman dengan dipungut bayaran, yang 
mencakup juga rumah makan, kafetaria, kantin, warung, bar dan sejenisnya termasuk jasa boga/katering".

\section{Dasar Hukum Pemungutan Pajak Restoran}

Menurut Siahaan (2010) pemungutan pajak restoran saat ini didasarkan pada dasar hukum yang jelas dan kuat, sehingga harus dipatuhi oleh masyarakat dan pihak yang terkait. Dasar hukum pemungutan pajak res-toran pada suatu kabupaten/kota adalah:

1. Undang-undang nomor 28 tahun 2009 tentang Pajak Daerah dan Retribusi Daerah

2. Undang-undang nomor 34 tahun 2000 yang merupakan perubahan atas Undang-undang nomor 18 tahun 1997 tentang Pajak Daerah dan Retribusi Daerah

3. Peraturan Pemerintah nomor 65 tahun 2001 tentang Pajak Daerah.

4. Peraturan daerah kabupaten/kota yang mengatur tentang Pajak Restoran.

5. Keputusan bupati/walikota yang mengatur tentang Pajak Restoran sebagai aturan pelaksanan Peraturan Daerah tentang Pajak Restoran pada kabupaten/ kota dimaksud.

\section{Dasar Pengenaan, Tarif, dan Cara Perhitungan Pajak Restoran}

Mengacu pada Pasal 40 UU No.28 tahun 2009, tarif pajak restoran ditetapkan sebesar $10 \%$ dan selanjutnya ditetapkan dengan Peraturan Daerah Kabupaten/kota yang bersangkutan. Berdasarkan Peraturan Daerah Kota Palu nomor 1 tahun 2011 Pasal 15 tarif Pajak Restoran ditetapkan sebesar 10\%. Setiap daerah atau kota diberi kewenangan untuk menentukan besarnya tarif pajak yang dipandang sesuai dengan kondisi masing-masing daerah kabupaten/ kota.

Secara umum perhitungan Pajak Res-toran adalah sesuai dengan rumus berikut ini

\section{Pajak Terutang $=$ Tarif pajak $\mathbf{x}$ dasar pengenaan pajak}

\section{Penetapan Saat Terutang dan Pembayaran Pajak Restoran}

Berdasarkan pasal 96 ayat (3) UU No. 28 Tahun 2009, pada saat ter-utangnya pajak restoran wajib pajak res-toran akan menerima Surat Ketetapan Pajak Daerah (SKPD). Jumlah pajak yang terutang sesuai dengan SKPD di-setorkan ke kas daerah atau bank yang ditunjuk mempergunakan Surat Setoran Pajak Daerah (SSPD). Berkaitan dengan pembayaran pajak restoran, pada pasal 101 Ayat (1) UU No. 28 Tahun 2009, Bupati/Wali kota menentukan tanggal jatuh tempo pembayaran dan penyetoran pajak restoran yang terutang paling lama 30 (tiga puluh) hari setelah saat terutangnya pajak.

\section{Sanksi Penagihan dengan Surat Paksa}


Mengacu pada pasal 100 ayat (1) UU No.28 Tahun 2009, Bupati/walikota dapat menerbitkan Surat Tagihan Pajak Daerah (STPD) jika pajak restoran dalam tahun berjalan tidak atau kurang dibayar. Wajib Pajak dikenakan sanksi administrasi berupa bunga dan atau denda. STPD diterbitkan baik terhadap wajib pajak yang melakukan kewajiban pajak yang dibayar sendiri maupun terhadap wajib pajak yang melaksanakan kewajiban pajak yang dipungut. Sanksi administrasi yang dikenakan mengacu pada Pasal 100 ayat (2) UU No.28 tahun 2009, besarnya sanksi administrasi berupa bunga sebesar $2 \%$ (dua persen) setiap bulan untuk paling lama 15 (lima belas) bulan sejak saat terutangnya pajak

Penagihan pajak dilakukan dengan terlebih dahulu memberikan surat teguran atau surat peringatan atau surat lain yang sejenis sebagai awal tindakan penagihan pajak. Surat teguran atau surat peringatan dikeluarkan tujuh hari sejak saat jatuh tempo pembayaran pajak dan dikeluarkan oleh pejabat yang ditunjuk oleh bupati/walikota. UU No. 28 Tahun 2009 Pasal 102 Ayat (2) menyebutkan bahwa penagihan pajak dengan Surat Paksa dilaksanakan berdasarkan Undang-undang nomor 19 tahun 2000 tentang Penagihan Pajak dengan Surat Paksa.

\section{METODE PENELITIAN}

Penelitian ini menggunakan kuesioner untuk mengetahui kepatuhan wajib pajak restoran. Kuesioner akan berisi pernyataan yang tersusun dan responden akan menjawab kuesioner dengan menggunakan skala Likert 1 sampai dengan 5 (1 = sangat tidak setuju, 5 = sangat setuju) untuk mengetahui opini wajib pajak.

Populasi dari penelitian ini adalah jumlah wajib pajak restoran di Kota Palu yang melaporkan pajaknya yaitu sejumlah 57 orang wajib pajak.

Kuesioner akan disebarkan pada wajib pajak restoran. Teknik pengumpulan sampel dalam penelitian ini menggunakan teknik acak (random) dengan menggunakan rumus Slovin untuk menentukan ukuran sampel. Pada teknik kuesioner ini, peneliti memberikan daftar pertanyaan dan nantinya akan dijawab oleh para responden tersebut. Tujuan penggunaan teknik adalah untuk mendapatkan jawaban responden mengenai pengaruh kesadaran, persepsi tentang keadilan dan kualitas pelayanan terhadap kepatuhan Wajib Pajak.

Lokasi penelitian pada wajib pajak restoran yang terdaftar di wilayah Kantor Dinas Pendapatan Pengelolaan Keuangan dan Aset Daerah di kota Palu. Waktu penelitian ini dilakukan pada tahun 2014.

Uji validitas digunakan untuk mengukur sah atau valid tidaknya suatu kuesioner. Instrumen yang dinyatakan valid jika alat ukur yang digunakan untuk mendapatkan 
(mengukur) data tersebut valid. Uji reliabilitas merupakan uji yang menunjukkan sejauh mana suatu alat pengukuran dapat dipercaya atau dapat diandalkan.

Uji Asumsi Klasik berupa uji normalitas, uji multikolinearitas, uji autokorelasi dan uji heteroskedastisitas harus dilakukan, karena penelitian menggunakan metode regresi linear berganda. Metode Regresi Linear Berganda dilakukan untuk menguji pengaruh kesadaran, persepsi tentang keadilan dan kualitas pelayanan pajak terhadap kepatuhan wajib pajak restoran dengan menggunakan SPSS versi 18.0.

Analisis Regresi Linear Berganda adalah pengaruh secara linier antara dua atau lebih variabel independen dengan va-riabel dependen. Analisis ini untuk menge-tahui apakah ada pengaruh antara variabel independen dengan variabel dependen dan untuk memprediksi nilai dari variabel dependen apabila nilai variabel independen mengalami kenaikan atau penurunan.

\section{HASIL PENELITIAN DAN ANALISA}

Table 1

Output Uji Regresi

Coefficients'

\begin{tabular}{|c|c|c|c|c|c|c|c|c|c|}
\hline \multirow[b]{2}{*}{ Nodel } & & \multicolumn{2}{|c|}{$\begin{array}{l}\text { Unstandardized } \\
\text { Coefficients } \\
\end{array}$} & \multirow{2}{*}{$\begin{array}{c}\text { Standardized } \\
\text { Coefficients } \\
\text { Beta }\end{array}$} & \multirow[b]{2}{*}{$t$} & \multirow[b]{2}{*}{$\mathrm{Sig}}$. & \multirow{2}{*}{$\begin{array}{c}\text { Correlations } \\
\text { Partial }\end{array}$} & \multicolumn{2}{|c|}{$\begin{array}{c}\text { Collinearity } \\
\text { Statistics }\end{array}$} \\
\hline & & $B$ & $\begin{array}{l}\text { Stol. } \\
\text { Enror }\end{array}$ & & & & & Tolerance & VIF \\
\hline \multirow[t]{5}{*}{1} & (Constant) & .048 & .517 & & .089 & .930 & & & \\
\hline & Kesadaran (X1) & .378 & .092 & .412 & 4.132 & .000 & .494 & .720 & 1.388 \\
\hline & Persepsi & & & & & & & & \\
\hline & $\begin{array}{l}\text { Tentang } \\
\text { Keadilan (X2) }\end{array}$ & .317 & .152 & .187 & 2.083 & .042 & .275 & .892 & 1.121 \\
\hline & $\begin{array}{l}\text { Kualitas } \\
\text { Pelayanan (X3) }\end{array}$ & .340 & .085 & .402 & 4.018 & .000 & .483 & .715 & 1.398 \\
\hline
\end{tabular}

a. Dependent Variable: Kepatuhan Wajib Pajak (Y)

\begin{tabular}{|c|c|c|c|c|c|c|}
\hline \multicolumn{7}{|c|}{ ANOVAb } \\
\hline Model & & $\begin{array}{l}\text { Sum of } \\
\text { Squares }\end{array}$ & $d f$ & Mean Square & $F$ & Sig. \\
\hline 1 & Regression & 23.497 & 3 & 7.832 & 28.953 & $.000^{8}$ \\
\hline & Residual & 14.338 & 53 & .271 & & \\
\hline & Total & 37.835 & 56 & & & \\
\hline
\end{tabular}

a. Predictors: (Constant), Kualitas Pelayanan (X3), Persepsi Tentang Keadilan (X2),

Kesadaran (X1)

b. Dependent Variable: Kepatuhan Wajb Pajak $(Y)$

Berdasarkan perhitungan Tabel 1 maka model persamaan regresi yang di-hasilkan adalah:

$$
Y=0,046+0,378 X_{1}+0,317 x_{2}+0,340 x_{3}+0,517
$$

Variabel independen kesadaran $\left(\mathrm{X}_{1}\right)$ memiliki koefisien regresi dengan tanda positif sebesar 0,378. Hal ini menunjukkan bahwa pengaruh kesadaran terhadap kepa-tuhan wajib pajak adalah positif. Nilai uji t untuk variabel kesadaran adalah sebesar 4,132 dengan tingkat signifikansi 0,000 (lebih kecil dari 0,05). 
Hasil penelitian ini konsisten dengan hasil penelitian yang dilakukan oleh Ika, dkk (2012), serta Puspa dan Zulaicha (2012) yang menyebutkan bahwa wajib pajak yang memiliki kesadaran lebih cenderung untuk patuh untuk membayar pajak. Dalam penel-tian ini ditemukan bahwa indikator variabel penyuluhan pajak merupakan indikator yang paling dominan terhadap kesadaran wajib pajak.

Variabel persepsi tentang keadilan adalah 0,317 dan nilai uji t sebesar 2,083 dengan tingkat signifikasi 0,042 berdasarkan data tersebut dapat disimpulkan bahwa $\mathrm{H}_{2}$ yang menyatakan bahwa persepsi tentang keadilan $\left(X_{2}\right)$ berpengaruh positif signifikan terhadap kepatuhan wajib pajak, diterima.

Hasil temuan ini konsisten dengan hasil penelitian yang dilakukan oleh Saad (2009), yang membuktikan bahwa wajib pajak melihat keadilan dari sistem pajak dari berbagai perspektif. Hasil yang sama juga dengan penelitian Anggraeni dan Harto (2012) di mana wajib pajak akan merasa adil jika hal yang dirasakan oleh masing-masing wajib pajak itu sama, misalnya dalam hal tarif pajak. Persepsi keadilan dari wajib pajak bisa mempengaruhi perilaku kepatuhan dari wajib pajak, semakin baik persepsi yang timbul dari diri mereka, maka semakin patuh wajib pajak tersebut dan jika persepsi mereka rendah maka mereka cenderung menjadi tidak taat pajak. Dalam penelitian ini variabel indikator keadilan vertikal merupakan indikator dominan sehingga wajib restoran di kota Palu merasa bahwa tarif pajak yang berlaku saat ini dirasakan sudah adil.

Variabel kualitas pelayanan adalah 0,340 dan nilai uji t sebesar 4,016 dengan tingkat signifikansi 0,000 . Dengan demikian $\mathrm{H}_{3}$ yang menyatakan bahwa kualitas pelayanan $\left(\mathrm{X}_{3}\right)$ berpengaruh positif dan signifikan terhadap kepatuhan wajib pajak diterima. Hasil temuan ini konsisten dengan hasil penelitian yang dilakukan oleh Alabede dkk (2011) yaitu "peningkatan kualitas pelayanan yang diberikan oleh otoritas pelayanan pajak akan meningkat-kan perilaku kepatuhan wajib pajak". Dalam hal ini kualitas pelayanan pajak bisa mengerahkan perilaku kepatuhan dari wajib pajak. Pelayanan yang lebih ramah dan kesigapan petugas pajak dalam menangani keluhan dan masalah dari wajib pajak akan menim-bulkan rasa puas dari wajib pajak.

Residual atau error term (e) adalah perbedaan antara nilai variabel Kepatuhan Wajib Pajak (Y) yang sebenarnya dan nilai prediksi (predicted value) pada masing-masing responden. Semakin kecil angka residual dibandingkan standardised residual (residual yang distandarkan), maka model regresi semakin baik untuk digunakan dalam memprediksi. Pada penelitian ini, persamaan regresi yang dihasilkan menunjukkan kalau model regresi baik digunakan dalam memprediksi.

Dalam penelitian ini variabel indikator yang paling tinggi adalah variabel sistem informasi perpajakan. Hal ini menunjukkan bahwa wajib pajak restoran merasa bahwa peraturan perpajakan mudah dimengerti dan tidak membingungkan, informatif dan memberikan 
jaminan keadilan bagi wajib pajak sehingga memotivasi mereka untuk taat pajak, hal ini terlepas dari kualitas sumber daya manusia di kantor pemerintahan yang mendapat jawaban dengan skor terendah.

Table 2

Output Uji Regresi

Model Summant?

\begin{tabular}{|c|c|c|c|c|c|}
\hline llodel & $R$ & RSpuare & $\begin{array}{l}\text { Adusted } \\
\text { RSopare }\end{array}$ & $\begin{array}{l}\text { Sitd Eroor of } \\
\text { the Estimate }\end{array}$ & $\begin{array}{l}\text { Dubinin- } \\
\text { Walson }\end{array}$ \\
\hline 1 & $.70^{8}$ & .621 & 600 & .5012 & 1.936 \\
\hline \multicolumn{6}{|c|}{ 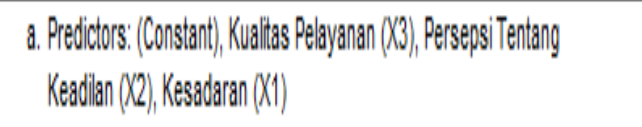 } \\
\hline
\end{tabular}

Nilai koefisien determinasi ( $R$ Square) yang dihasilkan regresi sebesar 0,621 menunjukkan bahwa kemampuan kesadaran, persepsi tentang keadilan dan kualitas layanan dalam menjelaskan variasi perubahan kepatuhan Wajib Pajak restoran di Kota Palu adalah sebesar $62,1 \%$ dan sisanya $37,9 \%$ dijelaskan oleh faktor lain. Dengan kata lain, kepatuhan wajib pajak restoran di Kota Palu dipengaruhi oleh kesadaran, persepsi tentang keadilan dan kualitas layanan sebesar $62,1 \%$, sedangkan sisa $37,9 \%$ dipengaruhi oleh faktor lain.

\section{KESIMPULAN}

Kesadaran $\left(\mathrm{X}_{1}\right)$ memiliki koefisien regresi dengan tanda positif. Hal ini menunjukkan bahwa pengaruh kesadaran terhadap kepatuhan wajib pajak adalah positif. Kesadaran berpengaruh signifikan terhadap kepatuhan wajib pajak, hal ini menunjukkan bahwa semakin tinggi tingkat kesadaran wajib pajak tentang perpajakan, semakin tinggi pula tingkat kepatuhan wajib pajak restoran, serta nilai positif menun-jukkan bahwa kesadaran wajib pajak res-toran di Kota Palu sudah baik.

Persepsi tentang keadilan $\left(\mathrm{X}_{2}\right)$ ber-pengaruh positif dan signifikan terhadap kepatuhan wajib pajak. Hal ini menun-jukkan bahwa semakin tinggi persepsi wajib pajak restoran tentang keadilan semakin tinggi pula tingkat kepatuhan wajib pajak restoran. Tanda positif menunjukkan bahwa persepsi tentang keadilan wajib pajak sudah baik.

Kualitas pelayan $\left(X_{3}\right)$ berpengaruh positif signifikan terhadap kepatuhan wajib pajak, Hal ini menunjukkan bahwa semakin tinggi kualitas pelayanan yang dirasakan oleh wajib pajak, semakin tinggi pula ting-kat kepatuhan wajib pajak dan nilai positif menunjukan bahwa kualitas pelayanan pajak di kota Palu sudah baik. 


\section{DAFTAR PUSTAKA}

Alabede, James O., Zaimah BT Zaionol Arifin, and Kamil MD Idris. 2011. Does Taxpayer's Financial Condition Moderate Determinants of Tax Compliance Behaviour Evidence from Nigeria. British Journal Of Economics, Finance and Management Sciences. (Vol 1) No.2: 109 - 128

Albari. 2008. Pengaruh Keadilan terhadap Kepuasan dan Kepatuhan Wajib Pajak. Unisia. (Vol XXXI) No.69: 280 - 293.

Anggraeni, Berutu Dian dan Puji Harto. 2012. Persepsi Keadilan Pajak terhadap Perilaku Kepatuhan Wajib Pajak Orang Pribadi WPOP. Diponegoro Journal of Accounting. (Vol 2) N0.2: 1 - 10.

Azmi, Anna A Che dan Kammal A Perumal. 2008. Tax Fairness Dimensions In An Asian Context The Malaysian Perspective. International Review of Business Research Papers Vol. 4 No.5.

Devas, Nick. 1989. Keuangan Pemerintahan Daerah di Indonesia. Jakarta: UI Press.

Ika, Sulistyawati Ardiani., Dian Indriana Tri Lestari dan Novi Widi Tiandari. (2012). Pengaruh Kesadaran Wajib Pajak Pelayanan Perpajakan dan Kepatuhan Wajib Pajak terhadap Kinerja Penerimaan Pajak. Studi Kasus pada Kantor Pelayanan Pajak Pratama Semarang Candisari. Jurnal Investasi. (Vol 8). No.1: 81 - 96.

Mardiasmo. 2011. Perpajakan. Edisi Revisi. Yogyakarta: Andi.

Musyarofah, Siti dan Adi Purnomo. 2008. Pengaruh Kesadaran dan Persepsi tentang Sanksi dan Hasrat Membayar Pajak terhadap Kepatuhan Wajib Pajak. Jurnal Akuntansi Manajemen Bisnis dan Sektor Publik. (Vol 5)

No.1: $34-50$.

Nurmantu, Safri. 2003. Pengantar Perpajakan Edisi 2. Jakarta. Granit

Oentari, Fuadi Arabella dan Yenni Mangoting. 2013. Pengaruh Kualitas Pelayanan Petugas Pajak, Sanksi Perpajakan dan Biaya Kepatuhan Pajak terhadap Kepatuhan Wajib Pajak UMKM. Tax and Accounting Review. (Vol 1). No.1 : 19 27.

Peraturan Daerah Kota Palu Palu Nomor 1 Tahun 2011 Tentang Pajak Daerah

Prianggono, Jarot dan Dax E.S Manuputty. 2011. Pengaruh Kualitas Pelayanan terhadap Kepuasan Wajib Pajak dalam Penerbitan Surat Tanda Nomor Kendaraan di Samsat Balikpapan. Jurnal Makna. (Vol 1). No.2 : 59 - 74.

Puspa, Arum Harjanti dan Zulaikha. 2012. Pengaruh Kesadaran Wajib Pajak Pelayanan Fiskus dan Sanksi Pajak terhadap Kepatuhan Wajib Pajak Orang Pribadi yang Melakukan Kegiatan Usaha dan Pekerjaan Bebas Studi di Wilayah KPP Pratama Cilacap. Diponegoro Journal of Accounting. (Vol 1) No.1: 1-8.

Saad, Natrah. 2009. Fairness Perceptions And Compliance Behaviour: The Case of Salaried Taxpayers in Malaysia After Implementation of The Self- Assessment System. eJournal of Tax Research. (Vol 8). No.1: 32 - 63.

Siahaan, Marihot Pahala. 2010. Pajak Daerah dan Retribusi Daerah Edisi Revisi. Depok: Raja Grafindo Persada.

Soemitro, Rahmat. 1991. Azas dan Dasar Perpajakan 1.PT Eresco Bandung. 
Suryadi. 2006. Model Hubungan Kausal Kesadaran Pelayanan Kepatuhan Wajib Pajak dan Pengaruhnya Terhadap Kinerja Penerimaan Pajak Suatu Survei Di Wilayah Jawa Timur. Jurnal Keuangan Publik. (Vol 4). No.1: 105 - 121.

Undang-Undang Republik Indonesia Nomor 28 tahun 2009 tentang Perubahan atas Undang - undang Nomor 34 tahun 2004 tentang Pajak dan Retribusi Daerah.

Zain, Mohammad. 2003. Manajemen Perpajakan. Jakarta: Salemba Empat. 